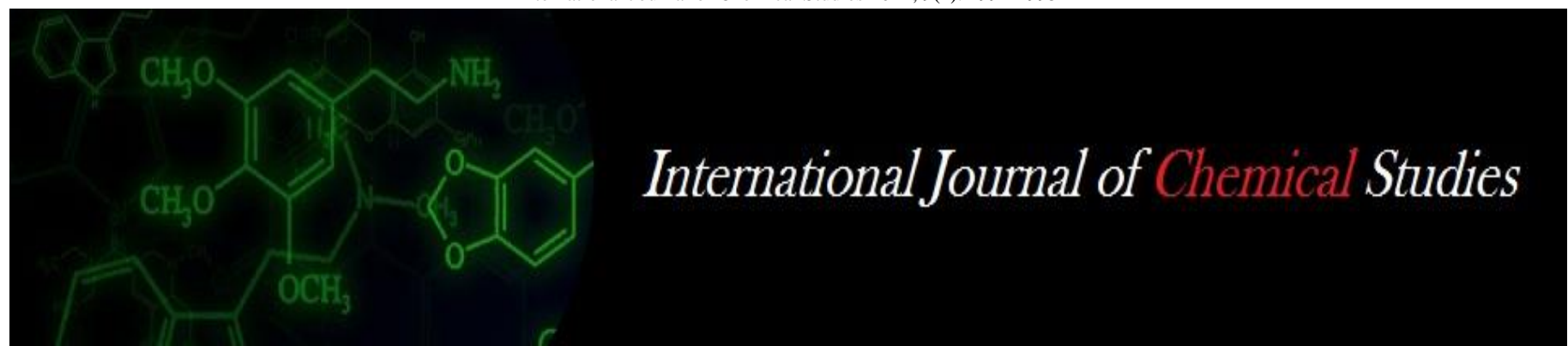

P-ISSN: 2349-8528

E-ISSN: 2321-4902

www.chemijournal.com

IJCS 2021; 9(1): 2992-2995

(C) 2021 IJCS

Received: 18-10-2020

Accepted: 30-11-2020

Bhavik K Patel

Main Cotton Research Station MCRS, Navsari Agricultural

University (NAU), Surat,

Gujarat, India

Prashant B Sandipan

Main Cotton Research Station (MCRS), Navsari Agricultural University (NAU), Surat,

Gujarat, India

SK Chawada

Krishi Vigyan Kendra, Navsari Agricultural University (NAU),

Surat, Gujarat, India

RK Patel

Krishi Vigyan Kendra, Navsari Agricultural University (NAU), Surat, Gujarat, India

Corresponding Author: Bhavik K Patel

Main Cotton Research Station MCRS, Navsari Agricultural

University (NAU), Surat,

Gujarat, India

\section{Evaluation of various combi product fungicides for the control of wilt (FOV) disease of cotton under in vitro condition of south Gujarat (India)}

\author{
Bhavik K Patel, Prashant B Sandipan, SK Chawada and RK Patel
}

DOI: https://doi.org/10.22271/chemi.2021.v9.i1ap.11683

\begin{abstract}
In this experiment, different districts of South Gujarat were closely examined for the presence of wilt disease in different cultivars/ $B t$ hybrids during the crop season to know the current scenario of wilt disease. The respective FOV wilt pathogen was purified, identified and isolated. Here, different combi fungicides were tested for their effect on the growth of Fusarium oxysporum f. sp. vasinfectum (FOV) using poisoned food technique. The technique involves cultivation of test organism on a medium containing the test chemicals. In this experiment, PDA was used as basal medium. Six combination products of fungicides were evaluated at three different concentrations by poisoned food technique for evaluating their efficacy against the Fusarium oxysporum f. sp. vasinfectum. Among them, combination products of fungicides, carbendazim $12 \%$ + mancozeb $63 \%$ significantly inhibited the growth of the Fusarium oxysporum $\mathrm{f}$. sp. vasinfectum and proved strongly fungitoxic in nature.
\end{abstract}

Keywords: Cotton, wilt, disease, fungicide

\section{Introduction}

Cotton (Gossypium spp.) is one of the most important fiber crops playing a key role in economic and social scenario of the globe. It is also known as "THE WHITE GOLD" or "THE KING OF FIBERS". It is oldest among the commercial crops of the world providing fiber for clothing of the mankind. Cotton is an important fiber yielding crop of global importance, which is grown in tropical and subtropical regions of more than 80 countries of the world. The major cotton producing countries are USA, China, India, Pakistan, Uzbekistan, Egypt, Argentina, Australia, Greece, Brazil and Turkey. In total global cotton production 70 per cent cotton production comes from the four countries, which includes China (27\%), India (22\%), USA (13\%) and Pakistan (8\%). For many developing and underdeveloped countries cotton export is the main source of foreign exchange earnings. The cotton crop is affected by plenteous pests, diseases and weeds etc. causing solemn economic losses in a crop. In the post Bt cotton era (2002 onwards) sucking pests like Aphids, Jassids, Thrips, Whitefly, Mealybugs, Myrid bugs and Mites continue to ravage the cotton crop and pose a serious threat to sustain and enhance cotton productivity (Tanweer, 2013) ${ }^{[6]}$. The wilt disease is responsible for serious losses to the crop in the central and western India on a large scale and on almost all the cultivated varieties of both $G$. arboreum and G. herbaceum, the two indigenous species, especially in black cotton soils of Maharashtra, Madhya Pradesh, Karnataka and Gujarat. At present the most of cultivated cultivars are susceptible to wilt disease (Fusarium oxysporum $\mathrm{f}$. sp. vasinfectum) and caused 54-60\% yield loss (Anon., 2003) ${ }^{[1]}$ because of reduced stand, stunted growth, small bolls and poor lint quality. The symptoms of Fusarium oxysporum f. sp. vasinfectum is both seed borne and soil borne and colonizes the roots and vascular system of susceptible cotton cultivars, causing root and vascular discoloration, wilting and sometimes death of the plant (Chen et al. 1985, Hillocks, 1992 and Davis et al., 1996) ${ }^{[2,4,3]}$. Looking to the frequent occurrence in one or other region and inflicting serious damage under South Gujarat region. Hence, the present investigation was undertaken to clarify deeply and thoroughly the wilt disease in these districts. 


\section{Material and Methods}

The different combi fungicides were tested for their effect on the growth of Fusarium oxysporum f. sp. vasinfectum (FOV) using poisoned food technique (Sinclair and Dhingra, 1985) [5]. The technique involves cultivation of test organism on a medium containing the test chemical. In all the experiments, PDA was used as basal medium. The required quantity of each chemical as shown in Discussion was incorporated aseptically in $100 \mathrm{ml}$ of PDA in $250 \mathrm{ml}$ flasks at the time of pouring the media in Petri plates. The medium shaken well to give uniform dispersal of the chemical and then in each Petri plates $20 \mathrm{ml}$ of medium will be poured aseptically and allowed to solidify. The Petri plates were inoculated with $5 \mathrm{~mm}$ diameter mycelial disc, cut from the periphery of seven days old fungus cultures. The mycelial disc was placed in the center of the plates in an inverted portion to make a direct contact with the poisoned medium and incubated at $27 \pm 2{ }^{\circ} \mathrm{C}$ for 10 days after inoculation. Simultaneously a suitable control was also maintained by growing the fungus on chemical free PDA. Observations on linear growth were recorded when full growth of fungus observed in control Petri plate.

The per cent growth inhibition (PGI) of the fungus in each treatment was calculated by using following formula given by Vincent (1947) ${ }^{[7]}$.

$\mathrm{PGI}=+\frac{100(\mathrm{DC}-\mathrm{DT})}{\mathrm{DC}}$

\section{Where}

PGI $=$ Per cent growth inhibition

$\mathrm{DC}=$ Average diameter of mycelial colony in control set $(\mathrm{mm})$
DT = Average diameter of mycelial colony of treated set (mm)

\section{Result and Discussion}

The different combinations of fungicides viz., pyraclostrobin $5 \%+$ mitiram 55\%, captan $70 \%+$ hexaconazole $5 \%$, carbendazim $12 \%+$ mancozeb $63 \%$, metalaxyl $8 \%+$ mancozeb $64 \%$, carbendazim $25 \%+$ iprodine $25 \%$, and hexaconazol $4 \%+$ Zineb $68 \%$ were evaluated at 1500, 2000 and $2500 \mathrm{ppm}$ concentrations. The observations regarding per cent inhibition of linear growth are presented in Table 1 and depicted in Plate 1 with Fig. 1.

Out of six combination products of fungicides efficacy of carbendazim $12 \%+$ mancozeb $63 \%$ was considering best with cent per cent growth inhibition of pathogen at all the three concentrations inhibited cent per cent growth of the pathogen and proved extremely fungitoxic.

The next best fungicide combination in order of merit at 2500ppm concentration was captan $70 \%$ + hexaconazole $5 \%$ $(89.53 \%)$ followed by hexaconazol $4 \%+$ zineb $68 \%$ $(82.55 \%)$, pyraclostrobin $5 \%+$ mitiram $55 \%(81.77 \%)$, carbendazim $25 \%+$ iprodine $25 \%(77.90 \%)$ and metalaxyl $8 \%+$ mancozeb $64 \%$ (68.98\%). The next best treatment combination at $2000 \mathrm{ppm}$ concentration was captan $70 \%+$ hexaconazole $5 \%(87.59 \%)$ followed by hexaconazol $4 \%+$ Zineb $68 \%(79.45 \%)$, pyraclostrobin $5 \%+$ mitiram $55 \%$ $(77.52 \%)$, carbendazim $25 \%+$ iprodine $25 \%(76.74 \%)$ and metalaxyl $8 \%+$ mancozeb $64 \%(60.46 \%)$ and at $1500 \mathrm{ppm}$ concentration was captan $70 \%+$ hexaconazole $5 \%(86.43 \%)$ followed by pyraclostrobin $5 \%+$ mitiram $55 \%(74.41 \%)$, hexaconazol $4 \%+$ Zineb $68 \%(70.54 \%)$ carbendazim $25 \%+$ iprodine $25 \%(67.82 \%)$ and metalaxyl $8 \%+$ mancozeb $64 \%$ $(58.13 \%)$.

Table 1: Inhibitory effect of combination products of fungicides against pathogen under in vitro test

\begin{tabular}{|c|c|c|c|c|}
\hline Sr. No. & Technical name of fungicides & Conc. (ppm) & Average colony diameter of pathogen $(\mathrm{mm})$ & Per cent inhibition over control \\
\hline \multirow{3}{*}{$\mathrm{T}_{1}$} & \multirow{3}{*}{ Pyraclostrobin 5\% + Mitiram 55\% } & 1500 & $4.74^{*}(22.00)^{* *}$ & 74.41 \\
\hline & & 2000 & $4.45(19.33)$ & 77.52 \\
\hline & & 2500 & $4.02(15.67)$ & 81.77 \\
\hline \multirow{3}{*}{$\mathrm{T}_{2}$} & \multirow{3}{*}{ Captan $70 \%+$ Hexaconazole $5 \%$} & 1500 & $3.48(11.67)$ & 86.43 \\
\hline & & 2000 & $3.34(10.67)$ & 87.59 \\
\hline & & 2500 & $3.08(9.00)$ & 89.53 \\
\hline \multirow{3}{*}{$\mathrm{T}_{3}$} & \multirow{3}{*}{ Carbendazim 12\% + Mancozeb 63\% } & 1500 & $0.71(0.00)$ & 100.00 \\
\hline & & 2000 & $0.71(0.00)$ & 100.00 \\
\hline & & 2500 & $0.71(0.00)$ & 100.00 \\
\hline \multirow{3}{*}{$\mathrm{T}_{4}$} & \multirow{3}{*}{ Metalaxyl 8\% + Mancozeb $64 \%$} & 1500 & $6.04(36.00)$ & 58.13 \\
\hline & & 2000 & $5.87(34.00)$ & 60.46 \\
\hline & & 2500 & $5.21(26.67)$ & 68.98 \\
\hline \multirow{3}{*}{$\mathrm{T}_{5}$} & \multirow{3}{*}{ Carbendazim $25 \%$ + Iprodine $25 \%$} & 1500 & $5.31(27.67)$ & 67.82 \\
\hline & & 2000 & $4.53(20.00)$ & 76.74 \\
\hline & & 2500 & $4.41(19.00)$ & 77.90 \\
\hline \multirow{3}{*}{$\mathrm{T}_{6}$} & \multirow{3}{*}{ Hexaconazole $4 \%+$ Zineb $68 \%$} & 1500 & $5.08(25.33)$ & 70.54 \\
\hline & & 2000 & $4.26(17.67)$ & 79.45 \\
\hline & & 2500 & $3.94(15.00)$ & 82.55 \\
\hline \multirow[t]{4}{*}{$\mathrm{T}_{7}$} & Control & - & $9.30(86.00)$ & - \\
\hline & S. Em. \pm & & 0.07 & \\
\hline & $\mathrm{CD}$ at $5 \%$ & & 0.20 & \\
\hline & $\mathrm{CV} \%$ & & 2.87 & \\
\hline
\end{tabular}

*Figures outside the parentheses indicate $\sqrt{\mathrm{x}}+0.5$ transformation value

**Figures in parentheses indicate original values 


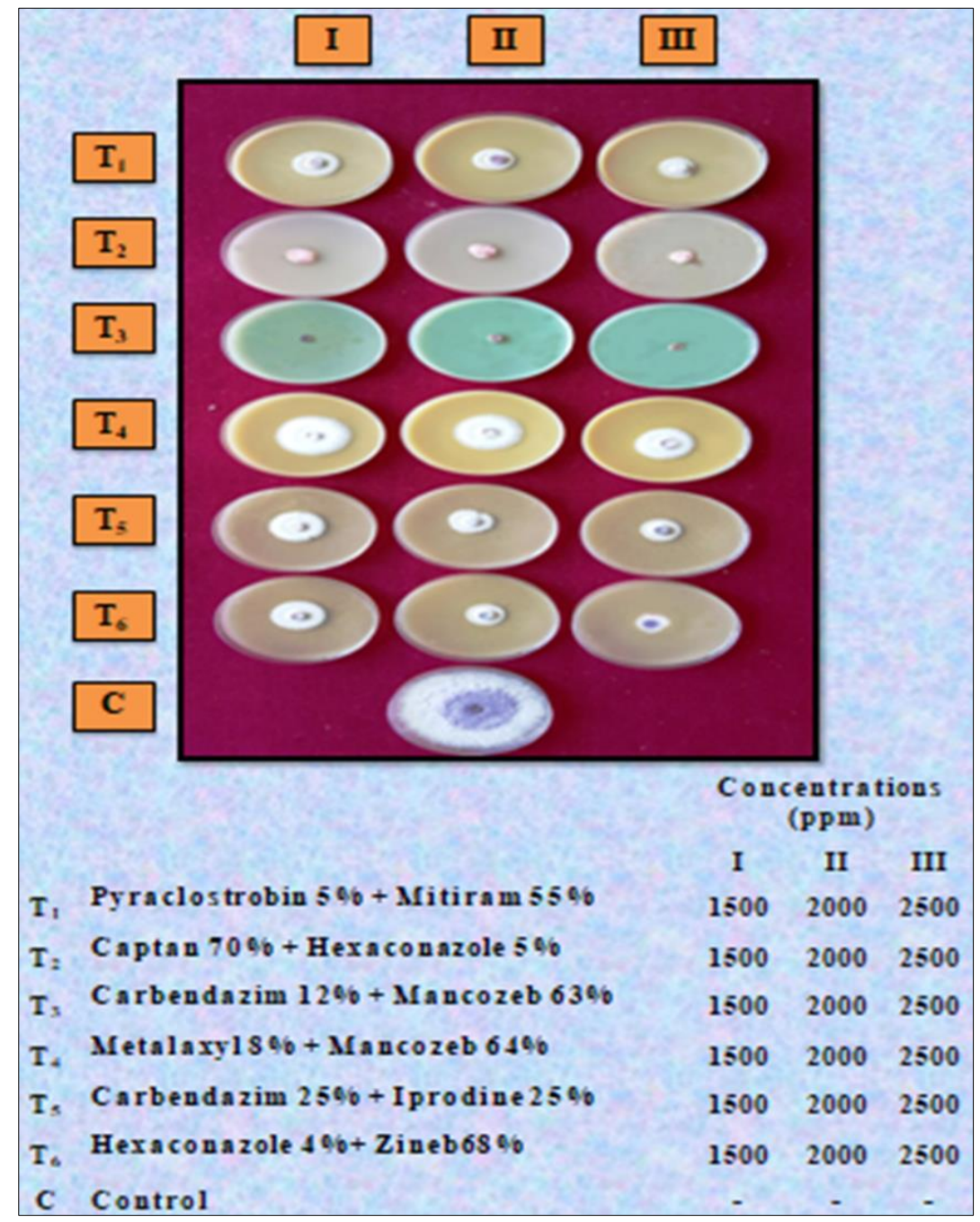

$\mathrm{T}_{1}$ Pyraclostrobin 5\% + Mitiram 55\% (Cabriotop 60G)

$\mathrm{T}_{2}$ Captan 70\% + Hexaconazole 5\% (Taqat 75\% WP)

$\mathrm{T}_{3}$ Carbendazim 12\% + Mancozeb 63\% (Sixer 75\%WP)

$\mathrm{T}_{4}$ Metalaxyl 8\% + Mancozeb 64\% (Ridomil 72\%MZ)

T5 Carbendazim 25\% + Iprodine 25\% (Quintal 50\%WP)

$\mathrm{T}_{6}$ Hexaconazole $4 \%$ + Zineb 68\% (Avtar 72\%WP)

T7 Control

Concentrations (ppm)

A 100

B 250

C 500

Plate 1: The observations regarding per cent inhibition of linear growth are presented

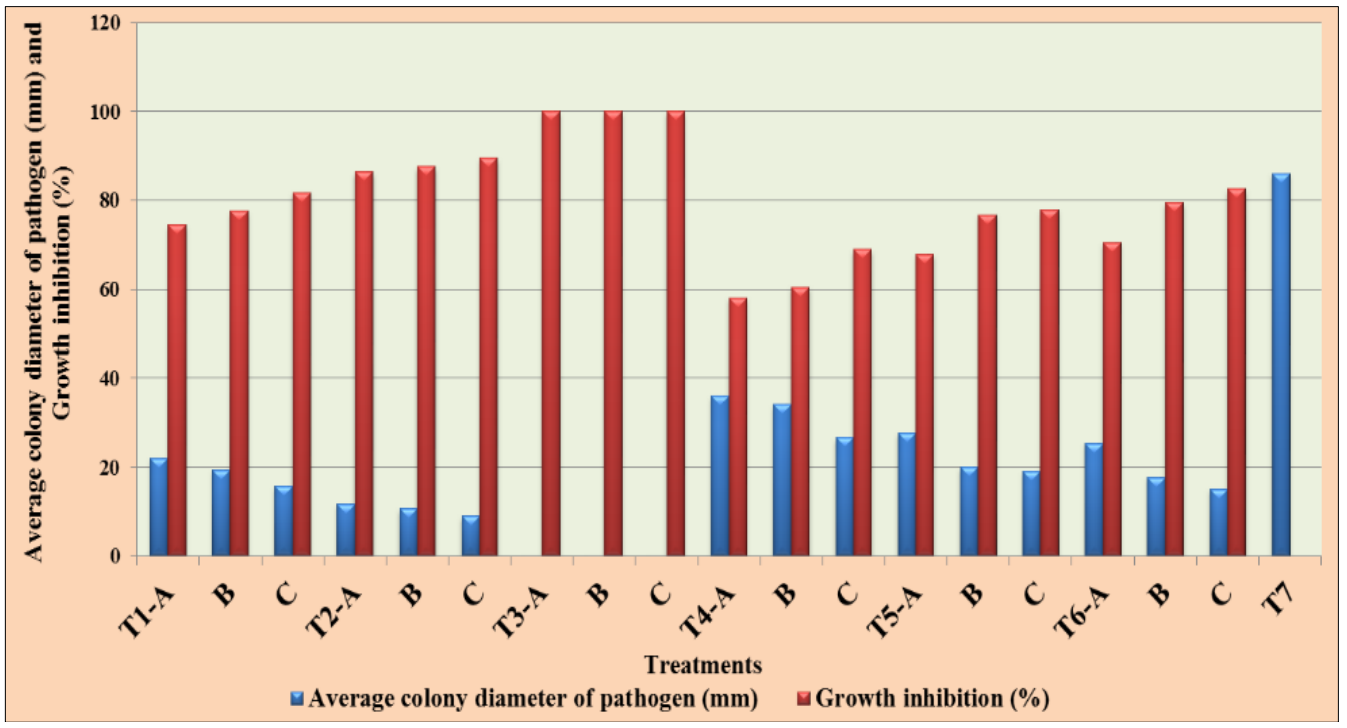

Fig 1: Inhibitory effect of combination products of fungicides against pathogen in vitro $\sim 2994 \sim$ 


\section{Acknowledgement}

Author is highly thankful to Main Cotton Research Station (MCRS), NAU, Surat (Gujarat) and Department of Plant Pathology, N. M. College of Agriculture, NAU, Navsari for providing the required facility and other necessary arrangements for conducting the experiment in a sensible way. This research paper is a part of M.Sc. thesis submitted to Navsari Agricultural University (NAU), Navsari (Gujarat).

\section{Reference}

1. Anonymous. Assessment of the impact and main dynamics of cotton diseases affecting in particular smallscale production systems in Southern-Africa 2003, https://www.icac.org/projects/commonfund/seacf_disease /proj11final.pdf accessed on 18 June 2017.

2. Chen Q, Ji X, Sun W. Identification of races of cotton wilt Fusarium in China. Journal of Agricultural Sciences 1985;6:1-6.

3. Davis RD, Moore NY, Kochman JK. Characterization of a population of Fusarium oxysporum f. sp. vasinfectum causing wilt of cotton in Australia. Australian Journal of Agricultural Research 1996;47:1143-1156.

4. Hillocks RJ. Fusarium wilt. In: Hillocks, R. J.(Ed.) Cotton diseases. Melksham UK. Redwood Press Ltd 1992, 127-160.

5. Sinclair JB, Dhingara OD. Basic Plant Pathology Methods. Publ. by CRC Press. Inc. Corporate Buld, M.W. Boca Raton, Florida 1985, 285-315.

6. Tanweer Asif. Pesticides in Cotton - The Road Ahead. National convention on India cotton: Gearing up for Global leadership 2013, 9-11.

7. Vincent JM. Distortion of fungal hyphae in presence of certain inhibitors $1947,159-850$. 